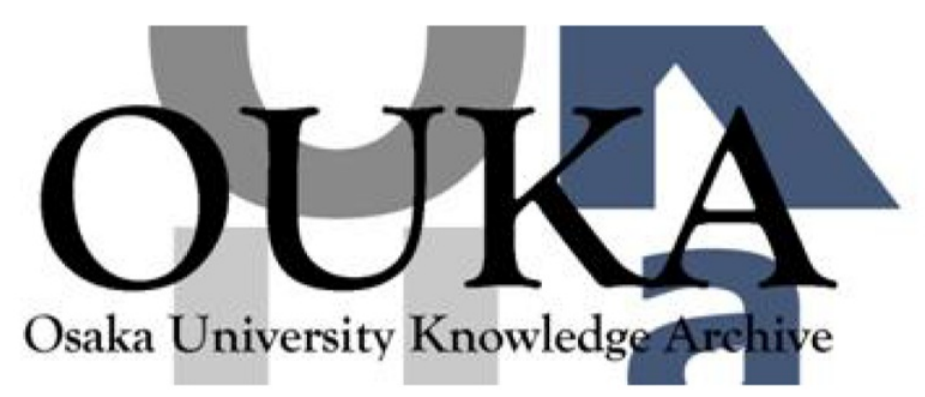

\begin{tabular}{|c|l|}
\hline Title & $\begin{array}{l}\text { Application of Thermodynamic Databases to the } \\
\text { Evaluation of Surface Tensions of Molten } \\
\text { Alloys, Salt Mixtures and Oxide Mixtures }\end{array}$ \\
\hline Author(s) & $\begin{array}{l}\text { Tanaka, Toshihiro; Hack, Klaus; Iida, Takamichi } \\
\text { et al. }\end{array}$ \\
\hline Citation & Zeitschrift für Metallkunde. 87(5) p. 380-p. 389 \\
\hline Issue Date & 1996 \\
\hline oaire:version & VoR \\
\hline URL & https://hdl.handle. net/11094/26520 \\
\hline rights & oCarl Hanser Verlag, München \\
\hline Note & \\
\hline
\end{tabular}

Osaka University Knowledge Archive : OUKA

https://ir. Library. osaka-u. ac. jp/

Osaka University 
Toshihiro Tanaka, Klaus Hack*, Takamichi Iida and Shigeta Hara

(Department of Materials Science and Processing, Faculty of Engineering, Osaka University, 2-1 Yamadaoka, Suita, Osaka 565, Japan; *GTT Technologies, Kaiserstrasse 100, 52134 Herzogenrath, Germany)

\section{Application of Thermodynamic Databases to the Evaluation of Surface Tensions of Molten Alloys, Salt Mixtures and Oxide Mixtures}

\begin{abstract}
The authors discuss the application of thermodynamic solution databases, which have been constructed so far to calculate thermodynamic properties and phase diagrams, to the evaluation of surface tensions of molten alloys, salt mixtures and oxide mixtures. In particular, the relationship between the excess Gibbs energy in the bulk phase and that in the "surface phase" which are used in Butler's equation for surface tension was derived for molten ionic solutions as well as molten alloys. In this work, the surface tensions of some liquid binary alloys, various molten salt mixtures, which mainly consist of alkali cations and halide anions, and some molten oxide mixtures, in particular binary silicate systems, were calculated and compared with experimental values.
\end{abstract}

\section{Introduction}

During the last three decades, various thermodynamic databases have been compiled to be mainly applied to the calculation of phase diagrams of alloys, salts and oxides [90Bal]. The accumulation and assessment of thermodynamic data and phase equilibrium information to establish those databases is sometimes called CALPHAD (Computer Calculation of Phase Diagrams) approach [92Nis]. The CALPHAD approach has been recognized to be useful in various aspects of materials science and engineering [90Bal, 92Nis]. If it would be possible to use the thermodynamic databases to evaluate physical properties of liquid solutions as well as phase equilibria, we could not only widen the applicability of those thermodynamic databases but also further the understanding of the physical properties of molten alloys, salt mixtures and oxide mixtures. In a previous work [94Tan], the authors discussed the application of the thermodynamic solution databases, which have been generated by Kaufman et al. [77Kau] for the calculation of phase diagrams of iron base alloys, to the evaluation of the surface tension of liquid iron alloys. In the calculation of the surface tension of those liquid alloys, we applied a procedure presented by Speiser et al. [87Spe, $89 \mathrm{Yeu}$ ] which is based on Butler's equation [32But] with a model for activity coefficients in a hypothetical "surface phase". In order to extend the above procedure to the calculation of the surface tension of molten salts and oxide mixtures, we need information on the excess Gibbs energy in the surface phase of those ionic melts. In the present work, we derive some relationships between the excess Gibbs energy in the bulk phase and that in the surface phase for molten ionic mixtures as well as molten alloys. Then, we discuss the application of some thermodynamic solution databases to calculate the surface tension of some molten alloys and ionic mixtures.

\section{Butler's Equation for the Surface Tension of A-B Binary Liquid Solutions}

Several authors have proposed calculations of the surface tension of liquid solutions by employing thermodynamic data; for example 1) Hoar and Melford: [57Hoa]; 2) Monma and Sudo: [61Mon1, 61Mon21; 3) Kasama: [78Kas]; 4) Speiser et al:: [87Spe, 89Yeu].

All of the above authors carried out the calculations for only liquid binary alloys, although their principles are based on Butler's equation [32But], which is expressed for the surface tension $\sigma$ of any A-B binary liquid solution as follows:

$$
\begin{aligned}
\sigma=\sigma_{\mathrm{A}}+ & \frac{R T}{A_{\mathrm{A}}} \ln \frac{\left(1-N_{\mathrm{B}}^{\mathrm{S}}\right)}{\left.1-N_{\mathrm{B}}^{\mathrm{B}}\right)}+\frac{1}{A_{\mathrm{A}}} \bar{G}_{\mathrm{A}}^{\mathrm{E}, \mathrm{S}}\left(T, N_{\mathrm{B}}^{\mathrm{S}}\right)- \\
& -\frac{1}{A_{\mathrm{A}}} \bar{G}_{\mathrm{A}}^{\mathrm{E}, \mathrm{B}}\left(T, N_{\mathrm{B}}^{\mathrm{B}}\right) \\
=\sigma_{\mathrm{B}}+ & \frac{R T}{A_{\mathrm{B}}} \ln \frac{N_{\mathrm{B}}^{\mathrm{S}}}{N_{\mathrm{B}}^{\mathrm{B}}}+\frac{1}{A_{\mathrm{B}}} \bar{G}_{\mathrm{B}}^{\mathrm{E}, \mathrm{S}}\left(T, N_{\mathrm{B}}^{\mathrm{S}}\right)- \\
& -\frac{1}{A_{\mathrm{B}}} \bar{G}_{\mathrm{B}}^{\mathrm{E}, \mathrm{B}}\left(T, N_{\mathrm{B}}^{\mathrm{B}}\right)
\end{aligned}
$$

where $R$ is the gas constant, $T$ : temperature, $\sigma_{\mathrm{X}}$ : surface tension of pure liquid $\mathrm{X}, A_{\mathrm{X}}$ : surface area in a monolayer of pure liquid $\mathrm{X}(\mathrm{X}=\mathrm{A}$ or $\mathrm{B}) . A_{\mathrm{X}}$ can be obtained from the following equation:

$A_{\mathrm{X}}=L N_{0}^{1 / 3} V_{\mathrm{X}}^{2 / 3}$

where $N_{0}$ : Avogadro number, $V_{\mathrm{X}}$ : molar volume of pure liquid X. $L$ in Eq. (2) is usually set to be 1.091 for liquid metals assuming closed packed structures. $N_{\mathrm{X}}^{\mathrm{S}}$ and $N_{\mathrm{X}}^{\mathrm{B}}$ in Eq. (1) are mole fractions of a component $X$ in a surface phase and a bulk phase, respectively; $\bar{G}_{\mathrm{X}}^{\mathrm{E}, \mathrm{S}}\left(T, N_{\mathrm{B}}^{\mathrm{S}}\right)$ : partial excess Gibbs energy of $\mathrm{X}$ in the surface phase as a function of $T$ and $N_{\mathrm{B}}^{\mathrm{S}} ; \bar{G}_{\mathrm{X}}^{\mathrm{E}, \mathrm{B}}\left(T, N_{\mathrm{B}}^{\mathrm{B}}\right)$ : partial excess Gibbs energy of $\mathrm{X}$ in the bulk phase as a function of $T$ and $N_{\mathrm{B}}^{\mathrm{B}}(\mathrm{X}=\mathrm{A}$ or $\mathrm{B})$. 
Table 1. List of liquid solutions for which surface tensions have been calculated so far from Eqs. (1) to (3) with the value of $\beta$.

\begin{tabular}{|c|c|c|}
\hline & $\beta$ & liquid solutions \\
\hline $\begin{array}{l}\text { Hoar and Melford } \\
\text { [57Hoa] }\end{array}$ & $1 / 2$ to $3 / 4$ & $\mathrm{Sn}-\mathrm{Pb}$ and $\mathrm{Pb}-\mathrm{In}$ \\
\hline \multirow[t]{2}{*}{$\begin{array}{l}\text { Monma and Sudo } \\
\text { [61Mon1, 61Mon2] }\end{array}$} & $\begin{array}{l}0.80 \text { to } 0.84 \\
\text { for alloys }\end{array}$ & $\mathrm{Cu}-\mathrm{Ni}$ and $\mathrm{Ni}-\mathrm{Mo}$ \\
\hline & $\begin{array}{l}0.90 \text { to } 0.94 \\
\text { for ionic solutions }\end{array}$ & $\mathrm{Cu}-\mathrm{Cu}_{2} \mathrm{O}, \mathrm{Cu}-\mathrm{Cu}_{2} \mathrm{~S}$ \\
\hline $\begin{array}{l}\text { Kasama } \\
{[78 \mathrm{Kas}]}\end{array}$ & 1 & $\mathrm{Ag}-\mathrm{Au}, \mathrm{Fe}-\mathrm{Mn}, \mathrm{Sn}-\mathrm{Pb}, \mathrm{Ag}-\mathrm{Pb}, \mathrm{Cu}-\mathrm{Pb}, \mathrm{Cu}-\mathrm{Sn}$ and $\mathrm{Fe}-\mathrm{Si}$ \\
\hline $\begin{array}{l}\text { Speiser et al. } \\
\text { [87Spe, } 89 \mathrm{Yeu}]\end{array}$ & $3 / 4$ & $\begin{array}{c}\mathrm{Fe}-\mathrm{Cu}, \mathrm{Cu}-\mathrm{Pb}, \mathrm{Sn}-\mathrm{Pb}, \mathrm{Ag}-\mathrm{Pb}, \mathrm{Pb}-\mathrm{In}, \mathrm{Bi}-\mathrm{Ag}, \mathrm{Cu}-\mathrm{Al} \\
\mathrm{Fe}-\mathrm{Si} \text { and } \mathrm{Ni}-\mathrm{Si}\end{array}$ \\
\hline $\begin{array}{l}\text { Tanaka and Iida } \\
\text { [94Tan] }\end{array}$ & $2 / 3,3 / 4$ & $\begin{array}{c}\mathrm{Ag}-\mathrm{Pb}, \mathrm{Sn}-\mathrm{Pb}, \mathrm{Cu}-\mathrm{Pb}, \mathrm{Cu}-\mathrm{Fe}, \mathrm{Cu}-\mathrm{Al}, \mathrm{Ni}-\mathrm{Si} \text {, a series of } \\
\text { iron base binary alloys and } \mathrm{Fe}-\mathrm{Cr}-\mathrm{Ni} \text { ternary alloy }\end{array}$ \\
\hline
\end{tabular}

\section{Relationship between Partial Excess Gibbs Energy in Bulk Phase and that in Surface Phase}

Butler derived Eq. (1) assuming an equilibrium between a bulk phase and a surface phase, which is regarded as a hypothetical independent phase. Since $\bar{G}_{\mathrm{X}}^{\mathrm{E}, \mathrm{B}}\left(T, N_{\mathrm{B}}^{\mathrm{B}}\right)$ can be obtained directly from thermodynamic databases, we only need the additional information on $\bar{G}_{\mathrm{X}}^{\mathrm{E}, \mathrm{S}}\left(T, N_{\mathrm{B}}^{\mathrm{S}}\right)$ in the surface phase. Speiser et al. [87Spe, 89Yeu], Hoar and Melford [57Hoa], Monma and Sudo [61Mon1, $61 \mathrm{Mon} 2$ ] and Kasama [78Kas] proposed their own models for $\bar{G}_{\mathrm{X}}^{\mathrm{E}, \mathrm{S}}\left(T, N_{\mathrm{B}}^{\mathrm{S}}\right)$, which can be summarized as follows [94Tan]:

$\bar{G}_{\mathrm{X}}^{\mathrm{E}, \mathrm{S}}\left(T, N_{\mathrm{B}}^{\mathrm{S}}\right)=\beta \cdot \bar{G}_{\mathrm{X}}^{\mathrm{E}, \mathrm{B}}\left(T, N_{\mathrm{B}}^{\mathrm{S}}\right)$

where $\beta$ is a parameter corresponding to the ratio of the coordination number $Z$ in the surface phase to that in the bulk phases, $Z^{\mathrm{S}} / Z^{\mathrm{B}}$.

Equation (3) means that $\bar{G}_{\mathrm{X}}^{\mathrm{E}, \mathrm{S}}\left(T, N_{\mathrm{B}}^{\mathrm{S}}\right)$, which has the same formula as $\bar{G}_{\mathrm{X}}^{\mathrm{E}, \mathrm{B}}\left(T, N_{\mathrm{B}}^{\mathrm{B}}\right)$, is obtained by replacing $N_{\mathrm{B}}^{\mathrm{B}}$ by $N_{\mathrm{B}}^{\mathrm{S}}$

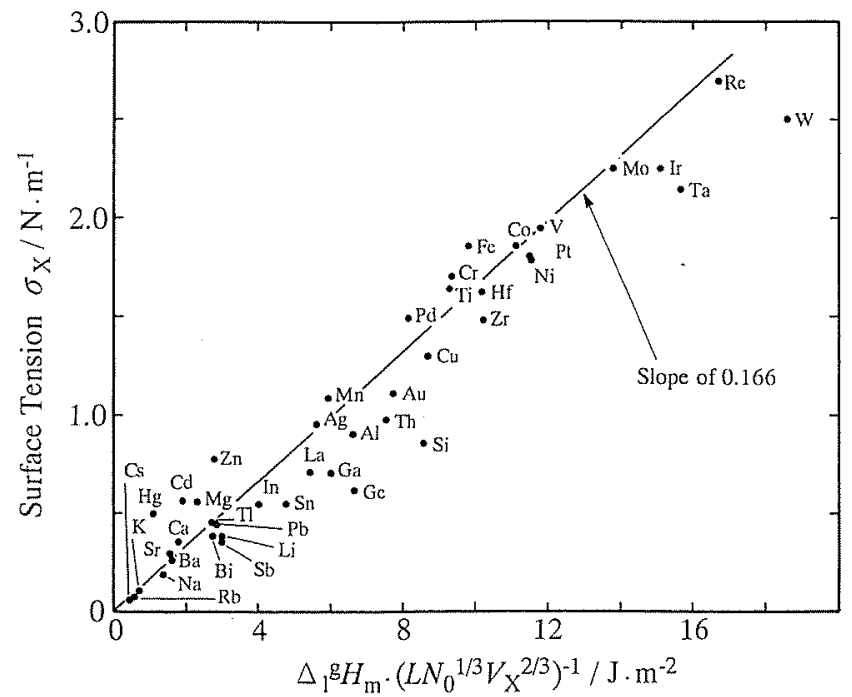

Fig. 1. Correlation of surface tension $\sigma_{\mathrm{X}}$ with $\Delta_{l}^{\mathrm{g}} H_{\mathrm{m}} \cdot\left(L N_{0}^{1 / 3} V_{\mathrm{X}}^{2 / 3}\right)^{-1}$ for various liquid metals $(L=1.091)$. in $\bar{G}_{\mathrm{X}}^{\mathrm{E}, \mathrm{B}}\left(T, N_{\mathrm{B}}^{\mathrm{B}}\right)(\mathrm{X}=\mathrm{A}$ or $\mathrm{B})$ and then multiplying $\beta$ to $\bar{G}_{\mathrm{X}}^{\mathrm{E}, \mathrm{B}}\left(T, N_{\mathrm{B}}^{\mathrm{S}}\right)$. The above four groups have reported calculations of surface tension of the liquid binary alloys shown in Table 1 . Using the respective value for $\beta$ also shown in Table 1 , the results agreed well with the measured values, though Hoar and Melford [57Hoa], and Monma and Sudo [61Mon1, 61Mon2] applied only a regular solution model for the excess Gibbs energy in Eq. (3). For example, Speiser et al. [87Spe, 89 Yeu] proposed Eq. (3) with $\beta=Z^{\mathrm{S}} / Z^{\mathrm{B}}$ on the basis of the assumption that the excess Gibbs energy is proportional to the coordination number, and that the coordination number in the surface phase is reduced by the ratio $Z^{\mathrm{S}} / Z^{\mathrm{B}}$ compared with that in the bulk phase because atoms in the surface lose some of their bonds with their nearest-neighbor atoms. The value of $\beta$, however, might be affected by other factors except $Z^{\mathrm{S}} / Z^{\mathrm{B}}$, for example, a change in binding energy in the surface phase, rearrangement of atom configurations and so on. Furthermore, when applying Eqs. (1) and (3) to ionic mixtures, no information on $Z^{S} / Z^{B}$ has been available. We, therefore, have determined $\beta$ as follows:



Fig. 2. Correlation of surface tension $\sigma_{\mathrm{X}}$ with $\Delta_{\mathrm{l}}^{\mathrm{g}} H_{\mathrm{m}} \cdot\left(L N_{0}^{1 / 3} V_{\mathrm{X}}^{2 / 3}\right)^{-1}$ for various ionic melts $(L=1)$. 
Table 2. Data for the determination of $\beta$ for liquid metals.

\begin{tabular}{|c|c|c|c|c|c|}
\hline$X$ & $\begin{array}{c}\Delta \Delta_{\mathrm{l}}^{\mathrm{g}} H_{\mathrm{m}, \mathrm{x}} \\
{\left[\mathrm{kJ} \cdot \mathrm{mol}^{-1}\right]}\end{array}$ & $\begin{array}{c}T_{\mathrm{m}} \\
{[\mathrm{K}]}\end{array}$ & {$\left[\begin{array}{c}V_{X} \\
{\left[10^{-6} \mathrm{~m}^{3} \mathrm{~mol}^{-1}\right]}\end{array}\right.$} & $\begin{array}{c}\Delta_{\mathrm{l}}^{\mathrm{g}} H_{\mathrm{m}, \mathrm{X}} /\left(L N_{0}^{1 / 3} V_{\mathrm{X}}^{2 / 3}\right) \\
{\left[\mathrm{J} \cdot \mathrm{m}^{-2}\right]}\end{array}$ & {$\left[\mathrm{N} \cdot \mathrm{m}^{-1}\right]$} \\
\hline $\mathrm{Li}$ & 157 & 452 & 13.4 & 3.02 & 0.398 \\
\hline $\mathrm{Na}$ & 107 & 371 & 24.8 & 1.37 & 0.191 \\
\hline $\mathrm{Mg}$ & 133 & 923 & 15.3 & 2.35 & 0.559 \\
\hline $\mathrm{Al}$ & 306 & 933 & 11.3 & 6.60 & 0.914 \\
\hline $\mathrm{Si}$ & 392 & 1687 & 11.1 & 8.56 & 0.865 \\
\hline $\mathrm{K}$ & 88 & 337 & 47.1 & 0.73 & 0.115 \\
\hline $\mathrm{Ca}$ & 158 & 1124 & 29.5 & 1.80 & 0.361 \\
\hline $\mathrm{Ti}$ & 438 & 1998 & 11.6 & 9.29 & 1.650 \\
\hline V & 485 & 1973 & 9.5 & 11.75 & 1.950 \\
\hline $\mathrm{Cr}$ & 351 & 2178 & 8.27 & 9.33 & 1.700 \\
\hline $\mathrm{Mn}$ & 246 & 1517 & 9.54 & 5.94 & 1.090 \\
\hline $\mathrm{Fe}$ & 357 & 1808 & 7.94 & 9.75 & 1.872 \\
\hline $\mathrm{Co}$ & 396 & 1765 & 7.60 & 11.13 & 1.873 \\
\hline $\mathrm{Ni}$ & 400 & 1728 & 7.43 & 11.42 & 1.778 \\
\hline $\mathrm{Cu}$ & 318 & 1356 & 7.94 & 8.68 & 1.303 \\
\hline $\mathrm{Zn}$ & 119 & 693 & 9.94 & 2.80 & 0.782 \\
\hline $\mathrm{Ga}$ & 280 & 303 & 11.4 & 6.01 & 0.718 \\
\hline $\mathrm{Ge}$ & 340 & 1232 & 13.2 & 6.62 & 0.621 \\
\hline $\mathrm{Rb}$ & 85 & 312 & 57.7 & 0.62 & 0.085 \\
\hline $\mathrm{Sr}$ & 160 & 1070 & 37.0 & 1.57 & 0.303 \\
\hline $\mathrm{Zr}$ & 581 & 2130 & 15.4 & 10.20 & 1.480 \\
\hline Mo & 600 & 2895 & 10.3 & 13.77 & 2.250 \\
\hline $\mathrm{Pd}$ & 351 & 1828 & 10.1 & 8.14 & 1.500 \\
\hline $\mathrm{Ag}$ & 266 & 1234 & 11.6 & 5.64 & 0.966 \\
\hline $\mathrm{Cd}$ & 104 & 594 & 14.0 & 1.95 & 0.570 \\
\hline & 239 & 430 & 16.3 & 4.04 & 0.556 \\
\hline $\mathrm{Sn}$ & 294 & 505 & 17.0 & 4.83 & 0.560 \\
\hline $\mathrm{Sb}$ & 195 & 904 & 18.8 & 3.00 & 0.367 \\
\hline $\mathrm{Cs}$ & 77 & 302 & 72.2 & 0.48 & 0.070 \\
\hline $\mathrm{Ba}$ & 178 & 1263 & 41.4 & 1.62 & 0.277 \\
\hline $\mathrm{La}$ & 409 & 1193 & 23.3 & 5.45 & 0.720 \\
\hline $\mathrm{Hf}$ & 571 & 2480 & 14.9 & 10.25 & 1.630 \\
\hline $\mathrm{Ta}$ & 761 & 3123 & 12.1 & 15.69 & 2.150 \\
\hline W & 823 & 3655 & 10.5 & 18.65 & 2.500 \\
\hline $\mathrm{Re}$ & 711 & 3440 & 9.96 & 16.69 & 2.700 \\
\hline Ir & 628 & 2727 & 9.61 & 15.10 & 2.250 \\
\hline $\mathrm{Pt}$ & 504 & 2047 & 10.3 & 11.56 & 1.800 \\
\hline $\mathrm{Au}$ & 358 & 1336 & 11.3 & 7.73 & 1.169 \\
\hline $\mathrm{Hg}$ & 61 & 234 & 14.7 & 1.11 & 0.498 \\
\hline $\mathrm{Tl}$ & 173 & 576 & 18.0 & 2.74 & 0.464 \\
\hline $\mathrm{Pb}$ & 189 & 601 & 19.4 & 2.84 & 0.458 \\
\hline $\mathrm{Bi}$ & 194 & 544 & 20.8 & 2.79 & 0.378 \\
\hline Th & 544 & 2088 & 22.1 & 7.51 & 0.978 \\
\hline
\end{tabular}

$\Delta_{\mathrm{l}}^{\mathrm{g}} H_{\mathrm{m}}, T_{\mathrm{m}}, V_{\mathrm{X}}, \sigma_{\mathrm{X}}:[88 \mathrm{Iid}]$

1) We assume that the surface tension $\sigma_{X}$ of pure liquid metals and pure ionic melts at their melting points is determined by the following relation:

$$
\begin{aligned}
A_{\mathrm{X}} \cdot \sigma_{\mathrm{X}} & =L N_{0}^{1 / 3} V_{\mathrm{X}}^{2 / 3} \cdot \sigma_{\mathrm{X}} \\
& =\left(-U_{\mathrm{X}}^{\mathrm{B}}\right)-\left(-U_{\mathrm{X}}^{\mathrm{S}}\right) \\
& =\left(-U_{\mathrm{X}}^{\mathrm{B}}\right)-\beta^{*} \cdot\left(-U_{\mathrm{X}}^{\mathrm{B}}\right) \\
& =\Delta_{\mathrm{l}}^{\mathrm{g}} H_{\mathrm{m}, \mathrm{X}}-\beta^{*} \cdot \Delta_{1}^{\mathrm{g}} H_{\mathrm{m}, \mathrm{X}}=\left(1-\beta^{*}\right) \cdot \Delta_{\mathrm{l}}^{\mathrm{g}} H_{\mathrm{m}, \mathrm{X}}
\end{aligned}
$$

where $U_{\mathrm{X}}^{\mathrm{B}}$ and $U_{\mathrm{X}}^{\mathrm{S}}$ are binding energies in the bulk phase and the surface phase, respectively, and $\beta^{*}=U_{\mathrm{X}}^{\mathrm{S}} / U_{\mathrm{X}}^{\mathrm{B}}$. In the above equation, surface entropy terms are neglected, and $\left(-U_{\mathrm{X}}^{\mathrm{B}}\right)$ is assumed to be approximately equal to evaporation energy at melting points, $\Delta_{1}^{\mathrm{g}} H_{\mathrm{m}, \mathrm{X}}$, which is obtained from the relation [88lid]: $\Delta_{\mathrm{l}}^{\mathrm{g}} H_{\mathrm{m}, \mathrm{X}}=\Delta_{\mathrm{S}}^{\mathrm{g}} H_{\mathrm{m}, \mathrm{X}}-\Delta_{\mathrm{S}}^{\mathrm{l}} H_{\mathrm{m}, \mathrm{X}}$ where $\Delta_{\mathrm{S}}^{\mathrm{g}} H_{\mathrm{m}, \mathrm{X}}$ and $\Delta_{\mathrm{S}}^{\mathrm{l}} H_{\mathrm{m}, \mathrm{X}}$ are sublimation energy and enthalpy of fusion of substance $\mathrm{X}$ at its melting point.
2) The relations between $\sigma_{\mathrm{X}}$ and $\Delta_{\mathrm{l}}^{\mathrm{g}} H_{\mathrm{m}} /\left(L N_{0}^{1 / 3} V_{\mathrm{X}}^{2 / 3}\right)$ for pure liquid metals and fused salts are shown in Figs. 1 and 2. The data [780gi, 79Kub, 86Gok, 87NIS, 88Iid] necessary to obtain these relations are listed in Tables 2 and 3. We applied $L=1.091$ in Eq. (4) for liquid metals. Since there has not been any exact information on the value of $L$ in Eqs. (2) and (4) for ionic melts, we used approximately $L=1$ for the fused salts. From the linear relations between $\sigma_{\mathrm{X}}$ and $\Delta_{\mathrm{g}}^{\mathrm{g}} H_{\mathrm{m}} /\left(L N_{0}^{1 / 3} V_{\mathrm{X}}^{2 / 3}\right)$ in Figs. 1 and 2 , the following values for $\beta^{*}$ were obtained:

$\beta^{*}=0.83$ for liquid metals

$\beta^{*}=0.94$ for ionic melts

The linear relation between $\sigma_{\mathrm{X}}$ and $\Delta_{\mathrm{l}}^{\mathrm{g}} H_{\mathrm{m}} /\left(L N_{0}^{1 / 3} V_{\mathrm{X}}^{2 / 3}\right)$ in Fig. 1 has been determined to correspond to a similar relation between $\sigma_{\mathrm{X}}$ and $\Delta_{\mathrm{l}}^{\mathrm{g}} H_{\mathrm{m}} / V_{\mathrm{X}}^{2 / 3}$ for liquid metals in "Fig. 5.13" on page 132 in [88Iid]. On the other hand, 
T. Tanaka et al.: Database Evaluation of Surface Tensions of Molten Alloys, Salt and Oxide Mixtures

Table 3. Data for the determination of $\beta$ for ionic melts.

\begin{tabular}{|c|c|c|c|c|c|c|c|c|}
\hline $\mathrm{X}$ & $\begin{array}{c}\Delta_{\mathrm{S}}^{\mathrm{g}} H_{\mathrm{m}, X} \\
{\left[\mathrm{~kJ} \cdot \mathrm{mol}^{-1}\right]}\end{array}$ & $\begin{array}{c}\Delta_{\mathrm{S}}^{\mathrm{l}} H_{\mathrm{m}, \mathrm{X}} \\
{\left[\mathrm{kJ} \cdot \mathrm{mol}^{-1}\right]}\end{array}$ & $\frac{d x}{\left[\mathrm{~g} \cdot \mathrm{cm}^{-3}\right]}$ & $\begin{array}{c}M_{\mathrm{X}} \\
{\left[\mathrm{g} \cdot \mathrm{mol}^{-1}\right]}\end{array}$ & $\begin{array}{c}T_{\mathrm{m}} \\
{[\mathrm{K}]}\end{array}$ & $\begin{array}{c}\frac{\Delta_{\mathrm{l}}^{\mathrm{g}} H_{\mathrm{m}, \mathrm{X}}}{L N_{0}^{1 / 3} V_{\mathrm{X}}^{2 / 3}} \\
{\left[\mathrm{Jm}^{-2}\right]}\end{array}$ & $\begin{array}{c}\frac{T_{\mathrm{m}}}{L N_{0}^{1 / 3} V_{\mathrm{X}}^{2 / 3}} \\
{\left[10^{3} \mathrm{Km}^{-2}\right]}\end{array}$ & $\begin{array}{c}\sigma_{\mathrm{X}} \\
{\left[\mathrm{Nm}^{-1}\right]}\end{array}$ \\
\hline $\mathrm{LiF}$ & 265.7 & 26.8 & 1.809 & 25.9 & 1121 & 4.80 & 22.5 & 0.236 \\
\hline $\mathrm{LiCl}$ & 196.6 & 19.9 & 1.502 & 42.4 & 883 & 2.26 & 11.3 & 0.128 \\
\hline $\mathrm{LiBr}$ & 190.8 & 17.7 & 2.529 & 86.8 & 823 & 1.94 & 9.2 & 0.110 \\
\hline LiI & 210.5 & 14.6 & 3.109 & 133.8 & 742 & 1.89 & 7.2 & 0.094 \\
\hline $\mathrm{NaF}$ & 264.8 & 33.5 & 1.950 & 42.0 & 1265 & 3.54 & 19.4 & 0.186 \\
\hline $\mathrm{NaCl}$ & 219.7 & 28.0 & 1.556 & 58.4 & 1074 & 2.03 & 11.4 & 0.114 \\
\hline $\mathrm{NaBr}$ & 205.9 & 26.2 & 2.339 & 102.9 & 1023 & 1.71 & 9.7 & 0.101 \\
\hline $\mathrm{NaI}$ & 203.3 & 23.6 & 2.742 & 149.9 & 933 & 1.48 & 7.7 & 0.086 \\
\hline $\mathrm{KF}$ & 227.6 & 28.2 & 1.910 & 58.1 & 1130 & 2.43 & 13.7 & 0.144 \\
\hline $\mathrm{KCl}$ & 207.9 & 26.6 & 1.527 & 74.6 & 1045 & 1.61 & 9.3 & 0.099 \\
\hline $\mathrm{KBr}$ & 203.8 & 25.5 & 2.122 & 119.0 & 1013 & 1.44 & 8.2 & 0.090 \\
\hline $\mathrm{KI}$ & 194.6 & 24.1 & 2.444 & 166.0 & 958 & 1.21 & 6.8 & 0.079 \\
\hline $\mathrm{RbF}$ & 218.0 & 23.0 & 2.925 & 104.5 & 1048 & 2.13 & 11.5 & 0.127 \\
\hline $\mathrm{RbCl}$ & 203.3 & 18.4 & 2.248 & 120.9 & 988 & 1.54 & 8.2 & 0.095 \\
\hline $\mathrm{RbBr}$ & 187.0 & 15.5 & 2.718 & 165.4 & 953 & 1.32 & 7.3 & 0.087 \\
\hline RbI & 179.9 & 12.6 & 2.906 & 212.4 & 913 & 1.14 & 6.2 & 0.077 \\
\hline CsF & 192.0 & 21.8 & 3.649 & 151.9 & 976 & 1.68 & 9.6 & 0.106 \\
\hline $\mathrm{CsCl}$ & 203.3 & 15.9 & 2.792 & 168.4 & 918 & 1.45 & 7.1 & 0.092 \\
\hline $\mathrm{CsBr}$ & 193.3 & 23.6 & 3.134 & 212.8 & 908 & 1.21 & 6.5 & 0.083 \\
\hline CsI & 192.5 & 23.8 & 3.197 & 259.8 & 894 & 1.07 & 5.6 & 0.072 \\
\hline $\mathrm{AgCl}$ & 214.2 & 13.0 & 4.872 & 143.3 & 728 & 2.50 & 9.1 & 0.179 \\
\hline $\mathrm{MgCl}_{2}$ & 209.2 & 43.1 & 1.682 & 95.2 & 987 & 1.34 & 7.9 & 0.062 \\
\hline $\mathrm{CaF}_{2}$ & 383.3 & 29.7 & 2.518 & 78.1 & 1691 & 4.25 & 20.3 & 0.387 \\
\hline $\mathrm{CaCl}_{2}$ & 292.9 & 28.5 & 2.085 & 111.0 & 1045 & 2.22 & 8.8 & 0.148 \\
\hline $\mathrm{SrF}_{2}$ & 361.9 & 29.7 & 3.470 & 125.6 & 1750 & 3.60 & 19.0 & $0.282^{*}$ \\
\hline $\mathrm{BaF}_{2}^{-}$ & 334.7 & 28.5 & 4.214 & 175.3 & 1563 & 3.02 & 15.4 & $0.253^{*}$ \\
\hline $\mathrm{ZnCl}_{2}$ & 155.2 & 10.3 & 2.525 & 136.3 & 591 & 1.20 & 4.9 & 0.054 \\
\hline $\mathrm{ZnBr}_{2}$ & 124.7 & 15.6 & 3.466 & 225.2 & 675 & 0.80 & 5.0 & 0.051 \\
\hline $\mathrm{CdCl}_{2}$ & 162.8 & 30.1 & 3.388 & 183.3 & 841 & 1.10 & 7.0 & 0.085 \\
\hline $\mathrm{CdBr}_{2}$ & 140.2 & 33.5 & 4.076 & 272.2 & 840 & 0.77 & 6.1 & 0.067 \\
\hline $\mathrm{HgBr}_{2}$ & 82.8 & 18.0 & 5.119 & 360.3 & 511 & 0.45 & 3.6 & 0.065 \\
\hline $\mathrm{PbCl}_{2}$ & 175.7 & 23.0 & 4.954 & 278.1 & 772 & 1.24 & 6.2 & 0.138 \\
\hline $\mathrm{LaCl}_{3}$ & 298.3 & 54.4 & 3.213 & 245.3 & 1128 & 1.61 & 7.4 & 0.123 \\
\hline $\mathrm{PrCl}_{3}$ & 291.8 & 50.6 & 3.227 & 247.3 & 1059 & 1.59 & 7.0 & 0.107 \\
\hline $\mathrm{ZrCl}_{4}$ & 103.3 & 37.7 & 1.643 & 233.0 & 710 & 0.29 & 3.1 & 0.007 \\
\hline
\end{tabular}

$\Delta_{\mathrm{S}}^{\mathrm{g}} H_{\mathrm{m}, \mathrm{X}}, \Delta_{\mathrm{S}}^{\mathrm{l}} H_{\mathrm{m}, \mathrm{X}}, T_{\mathrm{m}}:$ [79Kub] $d_{\mathrm{X}}$ (density), $\sigma_{\mathrm{X}}:$ [87NIS] $\left.\sigma_{\mathrm{X}}: 78 \mathrm{Ogi}\right] M_{\mathrm{X}}\left(=M_{\text {cation }}+M_{\text {anion }}\right)$ (molecular weight): [88Iid, 86Gok] $V_{\mathrm{X}}=$ $M_{\mathrm{X}} / d_{\mathrm{X}}, L=1 \Delta_{1}^{\mathrm{g}} H_{\mathrm{m}, \mathrm{X}}=\Delta_{\mathrm{S}}^{\mathrm{g}} H_{\mathrm{m}, \mathrm{X}}-\Delta_{\mathrm{S}}^{\mathrm{l}} H_{\mathrm{m}, \mathrm{X}}$

the value $\beta^{*}=0.94$ for ionic melts has been determined by a least-square regression method for the linear relation in Fig. 2.

3) We assume the following relation;

$\beta=\beta^{*}\left(=U_{\mathrm{X}}^{\mathrm{S}} / U_{\mathrm{X}}^{\mathrm{B}}\right):$ for pure liquid metals or ionic melts $=\bar{G}_{\mathrm{X}}^{\mathrm{E}, \mathrm{S}}\left(T, N_{\mathrm{B}}^{\mathrm{S}}\right) / \bar{G}_{\mathrm{X}}^{\mathrm{E}, \mathrm{B}}\left(T, N_{\mathrm{B}}^{\mathrm{S}}\right):$ for solutions

4) Figure 3 shows the relationship between $\sigma_{X}$ and $T_{\mathrm{m}} /\left(L N_{0}^{1 / 3} V_{\mathrm{X}}^{2 / 3}\right)$ for pure molten oxides as well as the ionic melts shown in Fig. 2. The values [93Ike] of $\sigma_{\mathrm{X}}, T_{\mathrm{m}}$ and $V_{\mathrm{X}}$ for pure molten oxides are listed in Table 4. Although the information on $\Delta_{l}^{\mathrm{g}} H_{\mathrm{m}}$ for molten oxides is not available, $\Delta_{\mathrm{l}}^{\mathrm{g}} H_{\mathrm{m}}$ can be associated to $T_{\mathrm{m}}$ as pointed out in [88Iid] for liquid metals. Consequently, Fig. 3 shows that molten oxides belong to the same category as the above ionic melts. Thus, from the above assumption 3), we have determined $\beta$ in Eq. (3) as follows:

$\beta=0.83$ for liquid alloys

$\beta=0.94$ for molten ionic mixtures including oxide mixtures

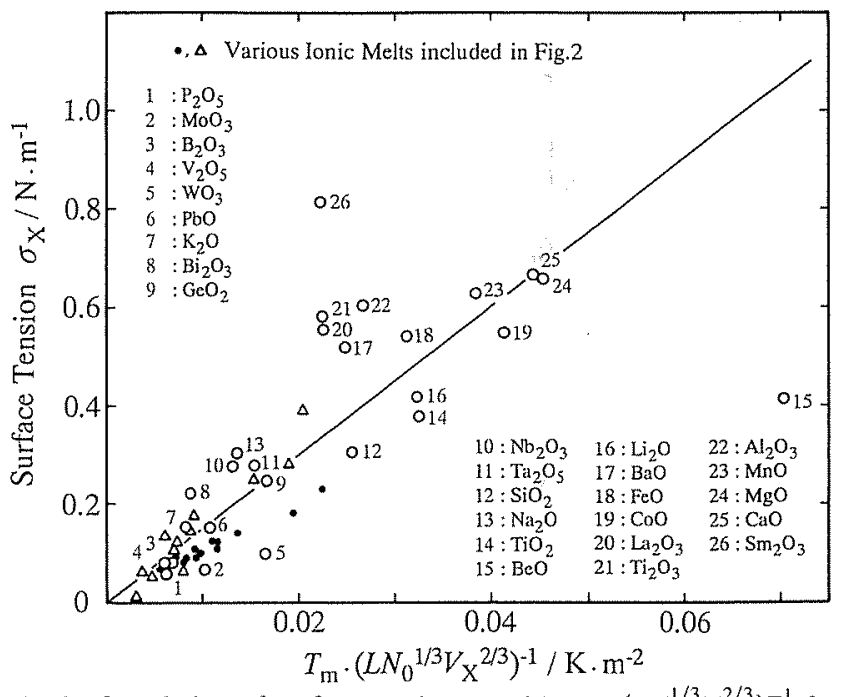

Fig. 3. Correlation of surface tension $\sigma_{\mathrm{x}}$ with $T_{\mathrm{m}} \cdot\left(L N_{0}^{1 / 3} V_{\mathrm{X}}^{2 / 3}\right)^{-1}$ for various ionic melts $(L=1)$. 
Table 4. Data for the calculation of the relation between $\sigma_{\mathrm{X}}$ and $T_{\mathrm{m}} /\left(L N_{0}^{1 / 3} V_{\mathrm{X}}^{2 / 3}\right)$ for molten oxides.

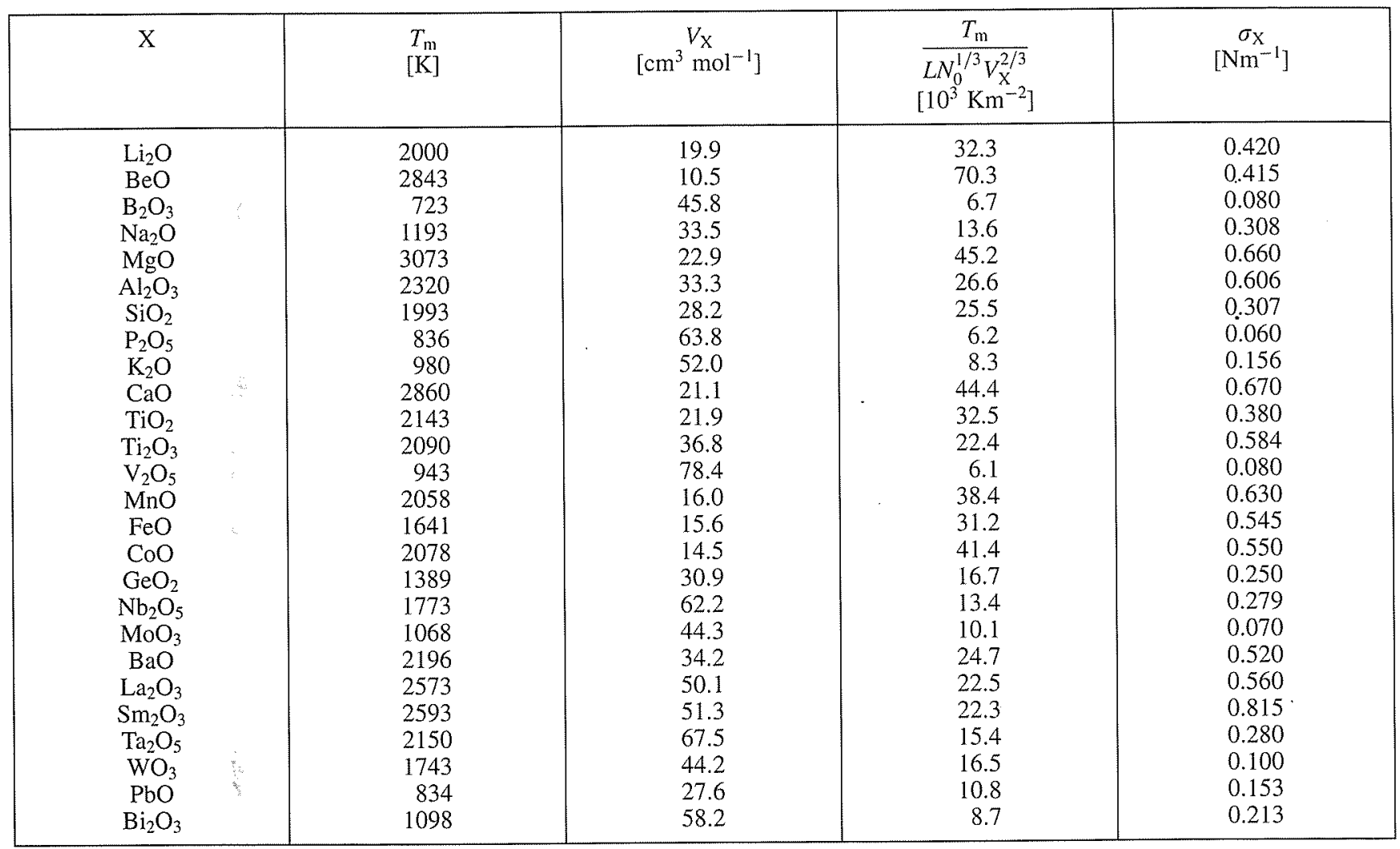

$T_{\mathrm{m}}, V_{\mathrm{X}}, \sigma_{\mathrm{X}}:[93$ Ike] $L=1$

Monma and Sudo [60Mon, 61Mon1] have already carried out treatments similar to points 1) to 3 ), given above and they obtained $\beta$-values of 0.80 to 0.84 for liquid metals and 0.90 to 0.94 for ionic melts. They applied Eqs. (1) to (3) to some liquid alloys [61Mon2], of which the excess Gibbs energies were expressed by a regular solution model. Skapski [48Ska] and Oriani [50Ori] also investigated the above treatments 1) and 2) for pure liquid metals.

\section{Procedure of Calculation of Surface Tensions of Liquid Solutions}

The surface tension $\sigma$ of liquid solutions can be calculated as follows:

1) Setting temperature $T$ and composition $N_{\mathrm{B}}^{\mathrm{B}}$ of a solution.

2) Inserting the values for surface tension $\sigma_{X}$ and molar volume $V_{X}$ of pure liquid substances at the above temperature in Eqs. (1) and (2).
3) Determining excess Gibbs energies in the bulk phase at the above temperature and composition, and substituting them in Eq. (1).

4) Then, one pair between the two equations on the righthand side of Eq. (1) becomes the equation with unknown $N_{\mathrm{B}}^{\mathrm{S}}$. This equation is solved for $N_{\mathrm{B}}^{\mathrm{S}}$, and the value of $N_{\mathrm{B}}^{\mathrm{S}}$ is substituted again into, e.g., the first equation of the right-hand side of Eq. (1) to calculate the surface tension $\sigma$ of the liquid solution on the left-hand side of Eq. (1). It should be emphasized here, that the solution for $N_{\mathrm{B}}^{\mathrm{S}}$ can be carried out in two ways: (1) mathematically explicit or (2) applying a numerical method. A mathematically explicit method has been used in the following applications whenever explicit polynomial expressions were available for the (partial) excess Gibbs energies, i.e. for liquid metals and salts. A numerical procedure was used for the case of the Gaye model which provides implicitly results for the (partial) Gibbs energies, i.e. for liquid oxides.

Table 5. Data for the calculation of surface tensions of liquid $\mathrm{Cu}-\mathrm{Pb}$ and $\mathrm{Fe}-\mathrm{Si}$ alloys.

\begin{tabular}{|c|c|c|c|c|}
\hline \multirow{2}{*}{ Elements } & $\begin{array}{c}\text { Surface Tension of pure substance } \\
\sigma_{\mathrm{X}}\left[\mathrm{mNm}^{-1}\right]\end{array}$ & \multicolumn{3}{|c|}{$\begin{array}{c}\text { Molar Volume of pure substance }[88 \mathrm{Iid}] \\
V_{\mathrm{X}}=V_{\mathrm{m}, \mathrm{X}}\left\{1+\alpha_{\mathrm{X}} \cdot\left(T-T_{\mathrm{m}, \mathrm{X}}\right)\right\}\left[10^{-6} \mathrm{~m}^{3} \cdot \mathrm{mol}^{-1}\right]\end{array}$} \\
\cline { 2 - 5 } & & $V_{\mathrm{m}, \mathrm{X}}\left[10^{-6} \mathrm{~m}^{3} \cdot \mathrm{mol}^{-1}\right]$ & $\alpha_{\mathrm{X}}\left[10^{-4} \mathrm{~K}^{-1}\right]$ & $T_{\mathrm{m}, \mathrm{X}}[\mathrm{K}]$ \\
\hline $\mathrm{Cu}$ & $1301^{*}(1373 \mathrm{~K})$ & 7.94 & 1.0 & 1356 \\
$\mathrm{~Pb}$ & $380^{*}(1373 \mathrm{~K})$ & 19.42 & 1.24 & 601 \\
$\mathrm{Fe}$ & $1729^{*}(1823 \mathrm{~K})$ & 7.94 & 1.3 & 1808 \\
$\mathrm{Si}$ & $759^{*}(1823 \mathrm{~K})$ & 11.1 & 1.4 & 1687 \\
\hline
\end{tabular}

* The values of $\sigma$ at pure compositions reported in literature, which are quoted to be compared with the calculated results for $\sigma$, have been selected as $\sigma_{\mathrm{X}}$. 


\section{Excess Gibbs Energy}

Liquid $\mathrm{Cu}-\mathrm{Pb}$ Alloys: [86Hay]

$G^{\mathrm{E}, \mathrm{B}}\left(T, N_{\mathrm{Pb}}\right)=\left(1-N_{\mathrm{Pb}}\right) N_{\mathrm{Pb}}\left\{A_{0}-B_{0} T+\left(A_{1}-B_{1} T\right)\left(1-2 N_{\mathrm{Pb}}\right)+\left(A_{2}-B_{2} T\right)\left(1-2 N_{\mathrm{Pb}}\right)^{2}+\left(A_{3}-B_{3} T\right)\left(1-2 N_{\mathrm{Pb}}\right)^{3}\right\}$

$A_{i}: A_{0}=27190.2, A_{1}=2229.2, A_{2}=-7029.2, A_{3}=-7397.6$

$B_{i}: B_{0}=4.21329, B_{1}=0.53584, B_{2}=-6.48832, B_{3}=-5.07992$

Liquid $\mathrm{Fe}-\mathrm{Si}$ Alloys: [91Lac]

$G^{\mathrm{E}, \mathrm{B}}\left(T, N_{\mathrm{Si}}\right)=\left(1-N_{\mathrm{Si}}\right) N_{\mathrm{Si}}\left\{L_{0}+L_{1}\left(1-2 N_{\mathrm{Si}}\right)+L_{2}\left(1-2 N_{\mathrm{Si}}\right)^{2}+L_{3}\left(1-2 N_{\mathrm{Si}}\right)^{3}\right\}$

$L_{0}=-164434.6+41.9773 T$

$L_{1}=-21.523 T$

$L_{2}=-18821.542+22.07 T$

$L_{3}=9695.8$

\section{Application of Thermodynamic Databases to the Evaluation of Surface Tension of Liquid Alloys}

In the previous work [94Tan], we investigated the dependence of surface tension of liquid alloys upon the value of $\beta$ in Eq. (3). In the present work, we recalculated the surface tension of liquid $\mathrm{Cu}-\mathrm{Pb}$ and $\mathrm{Fe}-\mathrm{Si}$ alloys with $L=1.091$ in Eq. (2) and with various values for $\beta$ shown in Table 1 and Eq. (8). The data of $\sigma_{\mathrm{X}}, V_{\mathrm{X}}$ and $G^{\mathrm{E}}\left(T, N_{\mathrm{B}}^{\mathrm{B}}\right)$ are given in Table 5. Thermodynamic data for $\mathrm{Cu}-\mathrm{Pb}$ alloys were taken from the assessment by Hayes et al. [86Hay] and for $\mathrm{Fe}-\mathrm{Si}$ alloys from Lacaze and Sundman [91Lac]. These data are part of the SGTE (Scientific Group Thermodata Europe) database [87Ans]. Partial excess Gibbs energies $\bar{G}_{\mathrm{A}}^{\mathrm{E}, \mathrm{B}}\left(T, N_{\mathrm{B}}^{\mathrm{B}}\right)$ and $\bar{G}_{\mathrm{B}}^{\mathrm{E}, \mathrm{B}}\left(T, N_{\mathrm{B}}^{\mathrm{B}}\right)$ of components $\mathrm{A}$ and $\mathrm{B}$ are obtained from the following relations;

$\bar{G}_{\mathrm{A}}^{\mathrm{E}, \mathrm{B}}\left(T, N_{\mathrm{B}}^{\mathrm{B}}\right)=G^{\mathrm{E}}\left(T, N_{\mathrm{B}}^{\mathrm{B}}\right)-N_{\mathrm{B}}^{\mathrm{B}} \frac{\partial G^{\mathrm{E}}\left(T, N_{\mathrm{B}}^{\mathrm{B}}\right)}{\partial N_{\mathrm{B}}^{\mathrm{B}}}$

$\bar{G}_{\mathrm{B}}^{\mathrm{E}, \mathrm{B}}\left(T, N_{\mathrm{B}}^{\mathrm{B}}\right)=G^{\mathrm{E}}\left(T, N_{\mathrm{B}}^{\mathrm{B}}\right)+\left(1-N_{\mathrm{B}}^{\mathrm{B}}\right) \frac{\partial G^{\mathrm{E}}\left(T, N_{\mathrm{B}}^{\mathrm{B}}\right)}{\partial N_{\mathrm{B}}^{\mathrm{B}}}$

As can be seen in Figs. 4 and 5, the calculated results for the surface tension in the two alloys are in good agreement with the experimental values [59Met, 73Jou, 64Dzh, 74Kaw,

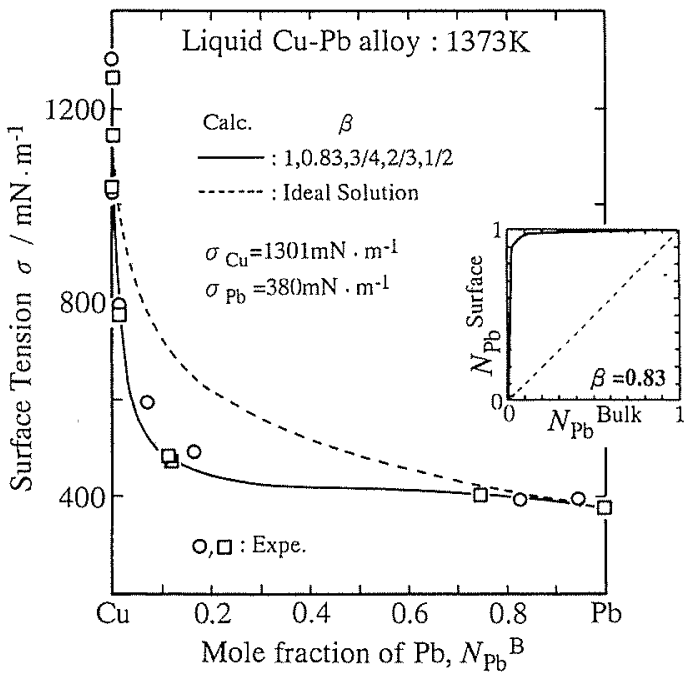

Fig. 4. Comparison of calculated results for the surface tension of liquid $\mathrm{Cu}-\mathrm{Pb}$ alloys with literature values, $\mathrm{O}$ : Metzger [59Met], $\square$ : Joud et al. [73Jou].
71She] using $\beta=0.83$ in Eq. (8). The curves in small squares in the above figures show the relation between $N_{\mathrm{B}}^{\mathrm{B}}$ and $N_{\mathrm{B}}^{\mathrm{S}}$ of the solute element $\mathrm{B}$ in the above alloys.

\section{Application of Thermodynamic Databases to the Evaluation of Surface Tensions of Molten Salt Mixtures}

Pelton et al. [83Pel, 88Pel] have assessed a thermodynamic database which permits calculation of thermodynamic properties and phase diagrams of salt mixtures according to the CALPHAD approach. In the present section, we discuss the application of this database to the evaluation of the surface tension of molten salt mixtures. Common ion systems considering the following ions have been treated:

Cations : $\mathrm{Li}^{+}, \mathrm{Na}^{+}, \mathrm{K}^{+}, \mathrm{Rb}^{+}, \mathrm{Cs}^{+}$;

Anions : $\mathrm{F}^{-}, \mathrm{Cl}^{-}, \mathrm{Br}^{-}, \mathrm{NO}_{3}^{-}$

Surface tension data of pure component salts, $\sigma_{X}$ in Eq. (1), were taken from the NIST database [87NIS]. We obtained $V_{\mathrm{X}}$ in Eq.(2) from the selected density $\rho_{\mathrm{X}}$ of pure ionic melt in the NIST database [87NIS] and the molar weight $M_{\mathrm{X}}$ of the cations and anions as follows;

$V_{\mathrm{X}}=\frac{M_{\text {cation }}+M_{\text {anion }}}{\rho_{\mathrm{X}}}$



Fig. 5. Comparison of calculated results for surface tension of liquid $\mathrm{Fe}-\mathrm{Si}$ alloys with literature values, O: Dzhemilev et al. [64Dzh], $\square$ Kawai et al. [74Kaw], $\triangle$ : Shergin et al. [71She]. 
Table 6. Values of surface tension and molar volume of pure molten salts and excess Gibbs energy $G^{\mathrm{E}, \mathrm{B}}\left(T, N_{\mathrm{A}}^{\mathrm{B}}, N_{\mathrm{B}}^{\mathrm{B}}\right)$ of molten salt mixtures in bulk phase. $G^{\mathrm{E}, \mathrm{B}}\left(T, N_{\mathrm{B}}^{\mathrm{B}}\right)$ in Eqs. (10) and (11) can be obtained from $G^{\mathrm{E}, \mathrm{B}}\left(T, N_{\mathrm{A}}^{\mathrm{B}}, N_{\mathrm{B}}^{\mathrm{B}}\right)$ with $N_{\mathrm{A}}^{\mathrm{B}}=1-N_{\mathrm{B}}^{\mathrm{B}}$.

\begin{tabular}{|c|c|c|c|c|}
\hline $\begin{array}{l}\text { Molten salt } \\
\text { mixtures }\end{array}$ & $\begin{array}{l}\text { Temp. } \\
{[\mathrm{K}]}\end{array}$ & $\begin{array}{c}\text { Surface tension of } \\
\text { pure molten salts } \\
\sigma_{\mathrm{X}}\left[\mathrm{mN} \cdot \mathrm{m}^{-1}\right]\end{array}$ & $\begin{array}{c}\text { Density of pure } \\
\text { molten salts } \\
\rho_{\mathrm{X}}\left[10^{-3} \mathrm{~kg} \cdot \mathrm{m}^{-3}\right]\end{array}$ & $\begin{array}{c}G^{\mathrm{E}, \mathrm{B}}\left(T, N_{\mathrm{A}}^{\mathrm{B}}, N_{\mathrm{B}}^{\mathrm{B}}\right) \\
\text { of molten salt mixtures } \\
\text { in bulk phase }\left[\mathrm{J} \cdot \mathrm{mol}^{-\mathrm{I}}\right]\end{array}$ \\
\hline $\mathrm{NaCl}-\mathrm{LiCl}$ & 1073 & $\begin{array}{l}\mathrm{NaCl}: 118.5 \\
\mathrm{LiCl}: 121.4\end{array}$ & $\begin{array}{l}1.56 \\
1.42\end{array}$ & $N_{\mathrm{NaCl}} N_{\mathrm{LiCl}}(-4686)$ \\
\hline $\mathrm{NaCl}-\mathrm{KCl}$ & 1073 & $\begin{array}{rl}\mathrm{NaCl}: & 114.0 \\
\mathrm{KCl} & 96.3\end{array}$ & $\begin{array}{l}1.56 \\
1.51\end{array}$ & $N_{\mathrm{NaCl}} N_{\mathrm{KCl}}\left(-2050-272 N_{\mathrm{NaCl}}\right)$ \\
\hline $\mathrm{LiCl}-\mathrm{KCl}$ & 1073 & $\begin{array}{l}\text { LiCl: } 114.5 \\
\mathrm{KCl}: 97.0\end{array}$ & $\begin{array}{l}1.42 \\
1.51\end{array}$ & $\begin{array}{l}N_{\mathrm{LiCl}} N_{\mathrm{KCl}}\{(-17570+7.627 \mathrm{~T}) \\
\left.\quad+(-377-4.958 T) N_{\mathrm{LiCl}}\right\}\end{array}$ \\
\hline $\mathrm{NaCl}-\mathrm{RbCl}$ & 1073 & $\begin{array}{l}\mathrm{NaCl}: 117.9 \\
\mathrm{RbCl}: 90.1\end{array}$ & $\begin{array}{l}1.56 \\
2.17\end{array}$ & $\begin{array}{l}N_{\mathrm{NaCl}} N_{\mathrm{RbCl}}\{(-3222+5.922 T) \\
\left.+(-335-5.245 \mathrm{~T}) N_{\mathrm{NaCl}}\right\}\end{array}$ \\
\hline $\mathrm{NaCl}-\mathrm{CsCl}$ & 1073 & $\begin{array}{c}\mathrm{NaCl}: 117.9 \\
\mathrm{CsCl}: 79.8\end{array}$ & $\begin{array}{l}1.56 \\
2.63\end{array}$ & $\begin{array}{l}N_{\mathrm{NaCl}} N_{\mathrm{CsCl}}\{(-4310+5.764 T) \\
\left.\quad+(418-5.901 T) N_{\mathrm{NaCl}}\right\}\end{array}$ \\
\hline $\mathrm{LiF}-\mathrm{KF}$ & 1073 & $\begin{array}{l}\text { LiF: } 256.5 \\
\text { KF: } 147.1\end{array}$ & $\begin{array}{l}1.83 \\
1.95\end{array}$ & $\begin{array}{c}N_{\mathrm{LiF}} N_{\mathrm{KF}}\{(-19251+4.521 T) \\
\left.+(-1205-3.146 T) N_{\mathrm{KF}}+4732\left(N_{\mathrm{KF}}\right)^{2}\right\}\end{array}$ \\
\hline $\mathrm{LiF}-\mathrm{NaF}$ & 1200 & $\begin{array}{l}\text { LiF: } 227.9 \\
\text { NaF: } 191.2\end{array}$ & $\begin{array}{l}1.77 \\
1.99\end{array}$ & $\begin{array}{c}N_{\mathrm{LiF}} N_{\mathrm{NaF}}\{(-7565+1.607 T) \\
\left.+(368+1.124 T) N_{\mathrm{NaF}}\right\}\end{array}$ \\
\hline $\mathrm{KF}-\mathrm{NaF}$ & 1073 & $\begin{array}{l}\text { KF: } 149.0 \\
\text { NaF: } 201.6\end{array}$ & $\begin{array}{l}1.95 \\
2.07\end{array}$ & $N_{\mathrm{KF}} N_{\mathrm{NaF}}(-335+2.541 \mathrm{~T})$ \\
\hline $\mathrm{NaBr}-\mathrm{KBr}$ & 1073 & $\begin{array}{l}\mathrm{NaBr}: 100.2 \\
\text { KBr: } 87.1\end{array}$ & $\begin{array}{l}2.30 \\
2.07\end{array}$ & $N_{\mathrm{NaBr}} N_{\mathrm{KBr}}\left(-2134-251 N_{\mathrm{NaBr}}\right)$ \\
\hline $\mathrm{RbBr}-\mathrm{KBr}$ & 1073 & $\begin{array}{l}\mathrm{RbBr}: 80.4 \\
\mathrm{KBr}: 87.1\end{array}$ & $\begin{array}{l}2.59 \\
2.07\end{array}$ & 0 \\
\hline $\mathrm{CsBr}-\mathrm{KBr}$ & 1073 & $\begin{array}{l}\text { CsBr: } 72.7 \\
\mathrm{KBr}: 87.1\end{array}$ & $\begin{array}{l}2.93 \\
2.07\end{array}$ & $N_{\mathrm{CsBr}} N_{\mathrm{KBr}}(377)$ \\
\hline $\mathrm{NaBr}-\mathrm{CsBr}$ & 1073 & $\begin{array}{l}\text { NaBr: } 100.2 \\
\text { CsBr: } 72.7\end{array}$ & $\begin{array}{l}2.30 \\
2.93\end{array}$ & $N_{\mathrm{NaBr}} N_{\mathrm{CsBr}}\left(-4728-209 N_{\mathrm{NaBr}}\right)$ \\
\hline $\mathrm{LiNO}_{3}-\mathrm{KNO}_{3}$ & 623 & $\begin{array}{l}\mathrm{LiNO}_{3}: 110.6 \\
\mathrm{KNO}_{3}: 111.4\end{array}$ & $\begin{array}{l}1.73 \\
1.86\end{array}$ & $\begin{array}{c}N_{\mathrm{LiNO}_{3}} N_{\mathrm{KNO}_{3}}\{(-7360-5.334 T) \\
\left.-2301 N_{\mathrm{LiNO}_{3}}+1937\left(N_{\mathrm{LiNO}_{3}}\right)^{2}\right\}\end{array}$ \\
\hline $\mathrm{NaNO}_{3}-\mathrm{KNO}_{3}$ & 623 & $\begin{array}{l}\mathrm{NaNO}_{3}: 116.6 \\
\mathrm{KNO}_{3}: 111.3\end{array}$ & $\begin{array}{l}1.87 \\
1.86\end{array}$ & $\begin{array}{c}N_{\mathrm{NaNO}_{3}} N_{\mathrm{KNO}_{3}}(-1640 \\
\left.-280 N_{\mathrm{NaNO}_{3}}\right)\end{array}$ \\
\hline $\mathrm{LiCl}-\mathrm{LiF}$ & 1073 & $\begin{array}{l}\text { LiCl: } 128 \\
\text { LiF: } 244.4\end{array}$ & $\begin{array}{l}1.42 \\
1.83\end{array}$ & $N_{\mathrm{LiCl}} N_{\mathrm{LiF}}(-1000)$ \\
\hline $\mathrm{KCl}-\mathrm{KF}$ & 1173 & $\begin{array}{l}\mathrm{KCl}: 92 \\
\mathrm{KF}: 117\end{array}$ & $\begin{array}{l}1.45 \\
1.88\end{array}$ & $\begin{array}{c}N_{\mathrm{KCl}} N_{\mathrm{KF}}\left\{3066-10621 N_{\mathrm{KF}}\right. \\
\left.+9125\left(N_{\mathrm{KF}}\right)^{2}\right\}\end{array}$ \\
\hline $\mathrm{NaCl}-\mathrm{NaF}$ & 1273 & $\begin{array}{l}\mathrm{NaCl}: 109 \\
\mathrm{NaF}: 185.2\end{array}$ & $\begin{array}{l}1.45 \\
1.95\end{array}$ & $N_{\mathrm{NaCl}} N_{\mathrm{NaF}}\left(1416+1283 N_{\mathrm{NaF}}\right)$ \\
\hline
\end{tabular}

Atomic weights: Element/Mx $\left[10^{-3} \cdot \mathrm{kg} \cdot \mathrm{mol}^{-1}\right]: \mathrm{Li} / 6.94, \mathrm{Na} / 22.99, \mathrm{~K} / 39.09, \mathrm{Rb} / 85.47, \mathrm{Cs} / 132.91, \mathrm{~F} / 18.998, \mathrm{Cl} / 35.453, \mathrm{Br} / 79.904$, $\mathrm{N} / 14.0067, \mathrm{O} / 15.999$

$\sigma_{\mathrm{X}}, \rho_{\mathrm{X}}:[87 \mathrm{NIS}], G^{\mathrm{E}, \mathrm{B}}\left(T, N_{\mathrm{A}}^{\mathrm{B}}, N_{\mathrm{B}}^{\mathrm{B}}\right):[83 \mathrm{Pel}, 88 \mathrm{Pel}]$

Excess Gibbs energies in the bulk phase of the common ion systems are listed with the values of $\sigma_{\mathrm{X}}, \rho_{\mathrm{X}}$ and $\left(M_{\text {cation }}+\right.$ $M_{\text {anion }}$ ) in Table 6 . Figure 6 shows the calculated results for the surface tension $\sigma$ of a few molten salt mixtures which have large negative excess Gibbs energies, using $\beta=0.94$, 0.83 and $3 / 4$ with $L=1$. The hatched zones in Fig. 6 show the uncertainties of the reported values [87NIS] for the surface tension of molten salt mixtures. The uncertainties have been determined from the scatter of the reported values of $\sigma_{\mathrm{X}}$ for pure substances in the NIST database [87NIS]. As shown in this figure, the values $3 / 4$ and 0.83 for $\beta$, which are adequate for liquid alloys, are unsuitable for the calculation of the surface tension of some molten salt mixtures. Figure 7 shows the comparison of the calculated results for the surface tension $\sigma$ of various molten salt mixtures with the values stored in the NIST database[87NIS]. It has been reported that the composition dependence of the surface tension of some molten salt mixtures shows large downward curvatures from the linearity [80Goo]. As shown in Fig. 7, some mixtures, for which calculated results have deviations from the literature values, show such composition dependences. It is, therefore, necessary to accumulate further information on the surface structures of molten salt mixtures in order to derive the excess Gibbs energy in the surface phase, which gives us more precise composition dependence of the surface tension of those mixtures.

\section{Application of Thermodynamic Databases to the Evaluation of the Surface Tension of Molten Oxide Mixtures}

We have applied the procedures described in the preceding sections to the evaluation of surface tensions of molten oxide mixtures. Equations (1), (2) and (3) have been 


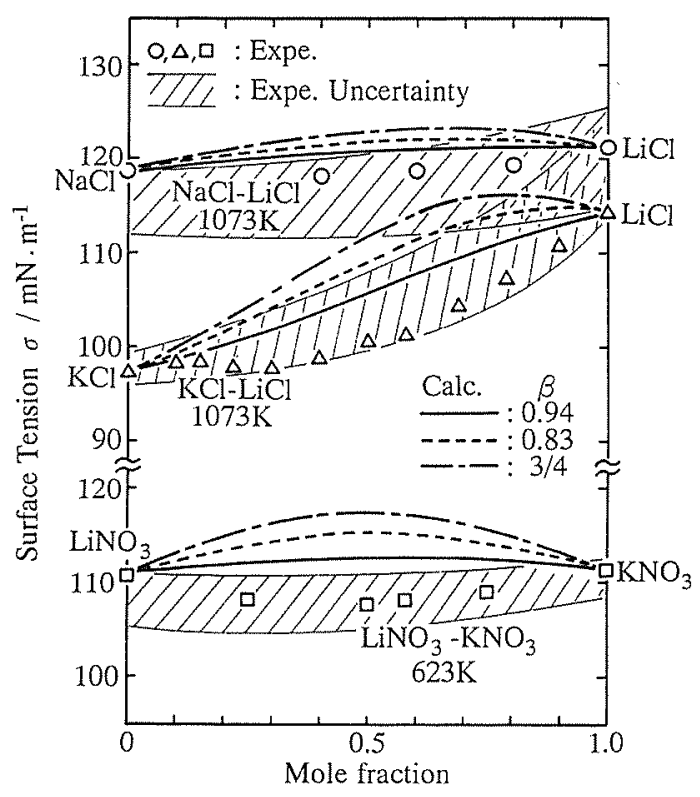

Fig. 6. Calculated results for surface tensions of some molten salt mixtures with various values of $\beta, O, \Delta, \square:$ [87NIS].

used with the conditions $L=1$ and $\beta=0.94$. Here, we have used the cell model developed by Gaye and Welfringer [84Gay] to obtain partial excess Gibbs energies of the components. Since in the cell model the Gibbs energy is not given in the form of a polynomial formula, one has to calculate numerically the partial excess Gibbs energies as well as the surface tension of molten oxide mixtures as follows:

1) At a given temperature and composition, the surface tensions $\sigma_{\mathrm{X}}$ and molar volumes $V_{\mathrm{X}}$ of the components are determined. In addition, the partial Gibbs energies of the components are calculated numerically in the cell model for a given $N_{\mathrm{B}}^{\mathrm{B}}$ in the bulk phase.

2) Then, changing the value of $N_{\mathrm{B}}^{\mathrm{S}}$ in the surface phase by a numerical procedure, $\bar{G}_{\mathrm{A}}^{\mathrm{E}, \mathrm{S}}\left(T, N_{\mathrm{B}}^{\mathrm{S}}\right)$ and $\bar{G}_{\mathrm{B}}^{\mathrm{E}, \mathrm{S}}\left(T, N_{\mathrm{B}}^{\mathrm{S}}\right)$ are calculated using the cell model and applying Eq. (3). Finding $\bar{G}_{\mathrm{A}}^{\mathrm{E}, \mathrm{S}}\left(T, N_{\mathrm{B}}^{\mathrm{S}}\right)$ and $\bar{G}_{\mathrm{B}}^{\mathrm{E}, \mathrm{S}}\left(T, N_{\mathrm{B}}^{\mathrm{S}}\right)$ to satisfy Eq. (1) for a certain $N_{\mathrm{B}}^{\mathrm{S}}$, the values of $N_{\mathrm{B}}^{\mathrm{S}}, \bar{G}_{\mathrm{A}}^{\mathrm{E}, \mathrm{S}}\left(T, N_{\mathrm{B}}^{\mathrm{S}}\right)$ and $\bar{G}_{\mathrm{B}}^{\mathrm{E}, \mathrm{S}}\left(T, N_{\mathrm{B}}^{\mathrm{S}}\right)$ are substituted again into Eq. (1) to determine $\sigma$ of the molten oxide mixture.

In this work, we have calculated the surface tension of molten $\mathrm{CaO}-\mathrm{SiO}_{2}(1873 \mathrm{~K})$ and $\mathrm{MnO}-\mathrm{SiO}_{2}(1843 \mathrm{~K})$ binary mixtures. The values of surface tension, molar volume of pure substances and energy parameters $W_{i j}$ and $E_{i j}$ in the cell model are shown in Table 7 [56Bon, 84Gay, 87Mil, 87NIS, 88Har, 931ke]. Since the values for $\sigma_{\mathrm{X}}$ of pure liquid $\mathrm{CaO}$ and $\mathrm{MnO}$ have not been obtained experimentally, we determined $\sigma_{\mathrm{CaO}}$ and $\sigma_{\mathrm{MnO}}$ in Table 7 considering estimated values reported by Boni and Darge [56Bon], Mills and Keene [87Mil], Hara et al. [88Har] and Ikemiya et al. [93Ike]. Figures 8 and 9 show the comparison of the calculated results for the surface tension of the above molten oxide mixtures with the experimental value ranges, which were determined from the reported values [51 Kin, 67Muk, $69 \mathrm{Ono}, 71 \mathrm{Sha}, 74 \mathrm{Gun}, 81 \mathrm{Muk}$ ]. In those figures, the dotted curves indicate those calculations, for which concentrations of the components in the surface phase exceed the composition range of the liquid phase, as shown in Table 8, for which the parameters of the cell model have been assessed. As can be seen in these figures, the composition dependence of the calculated values agree with the experimental results. However, when calculating the surface tension of molten oxide mixtures, one has to consider the following issues which result from the high melting points of pure oxides:

1) The provision of reliable information on the surface tension of pure molten oxides below their melting points.

2) The limitation of the composition range in the liquid in which the thermodynamic data and functions can be applied.

\section{Concluding Remarks}

In this paper, some relationships between the excess Gibbs energy in the bulk phase and that in the surface phase of molten alloys and ionic mixtures have been discussed. Furthermore, surface tensions of molten alloys, salt mixtures and oxide mixtures have been calculated using the thermodynamic properties of these phases. The thermody-
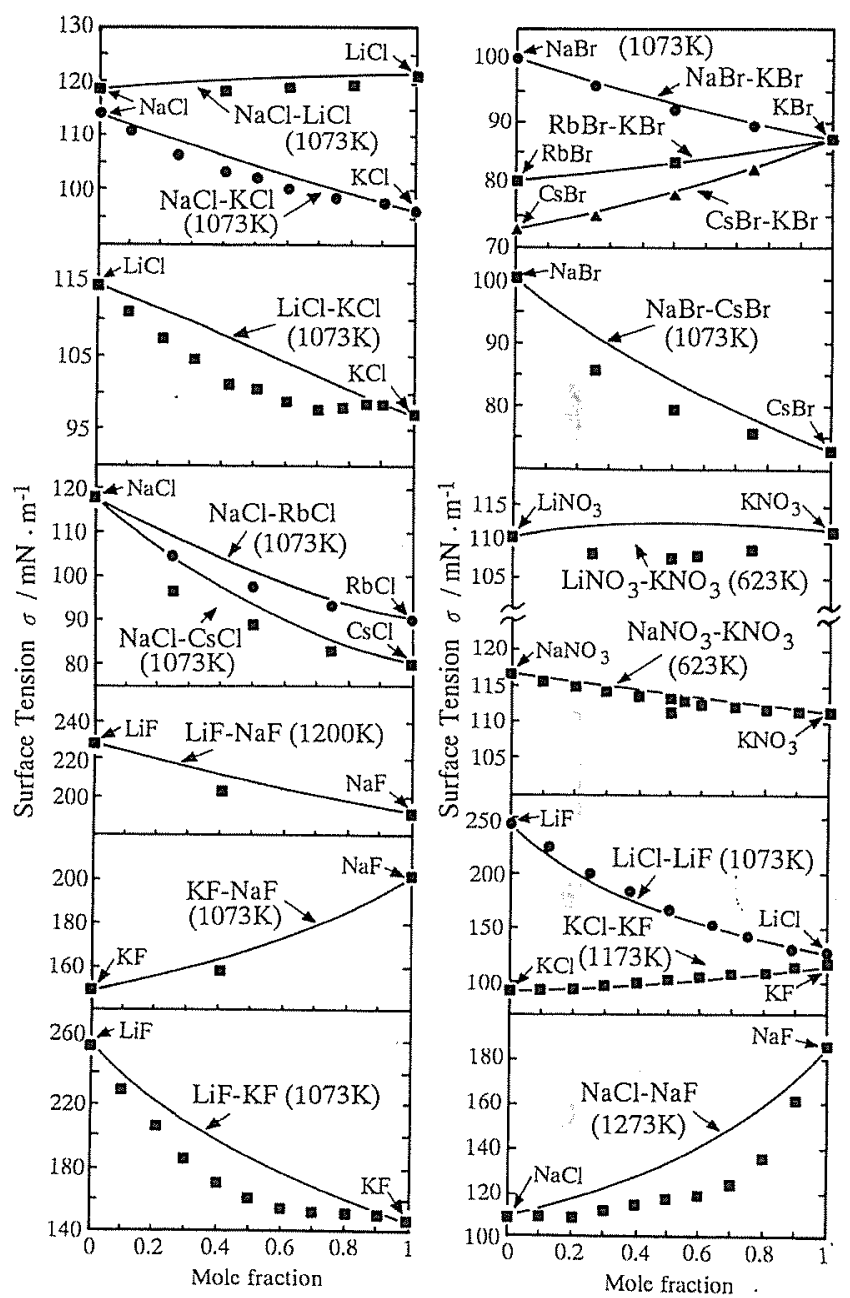

Fig. 7. Comparison of calculated results for surface tensions of various molten salt mixtures with the literature values [87NIS]. Calculated results: 一; literature values: $\mathbf{0}, \mathbf{\Delta}$. 

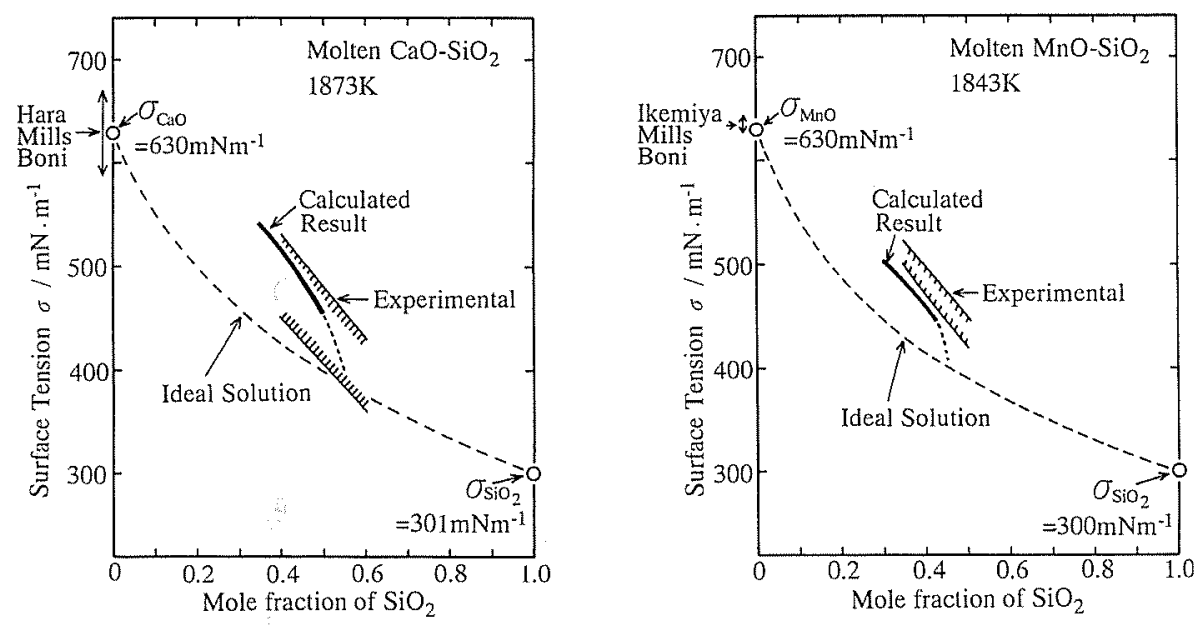

Fig. 8. (left) Comparison of calculated results for surface tension of molten $\mathrm{CaO}-\mathrm{SiO}_{2}$ mixtures with the experimental results [51Kin, $69 \mathrm{Ono}$, 71Sha, 74Gun, 81Muk].

Fig. 9. (right) Comparison of calculated results for surface tension of molten $\mathrm{MnO}-\mathrm{SiO}_{2}$ mixtures with the experimental results [51 Kin, 67Muk].

Table 7. Values for the calculation of surface tensions of molten oxide mixtures.

\begin{tabular}{|c|c|}
\hline $\mathrm{X}$ & Molar Volume $\left[\mathrm{m}^{3} \cdot \mathrm{mol}^{-1}\right][87 \mathrm{Mil}]$ \\
\hline $\mathrm{CaO}$ & $20.7 \cdot\left\{1+0.01 \cdot 10^{-2} \cdot(T-1773)\right\} \cdot 10^{-6}$ \\
$\mathrm{MnO}$ & $15.6 \cdot\left\{1+0.01 \cdot 10^{-2} \cdot(T-1773)\right\} \cdot 10^{-6}$ \\
$\mathrm{SiO}_{2}$ & $27.516 \cdot\left\{1+0.01 \cdot 10^{-2} \cdot(T-1773)\right\} \cdot 10^{-6}$ \\
\hline
\end{tabular}

\begin{tabular}{|c|c|c|}
\hline $\mathrm{X}$ & $\sigma_{\mathrm{x}}$ : Surface Tension $\left[\mathrm{mNm}^{-1}\right]$ & Present work \\
\hline & Literature values & $630(1873 \mathrm{~K})$ \\
$\mathrm{CaO}$ & $670(1823 \mathrm{~K})[88 \mathrm{Har}], 586(1773 \mathrm{~K})[56 \mathrm{Bon}], 625(1773 \mathrm{~K})[87 \mathrm{Mil}]$ & $630(1843 \mathrm{~K})$ \\
$\mathrm{MnO}$ & $630(\mathrm{~m} . \mathrm{p}).[93 \mathrm{Ike}], 641(1773 \mathrm{~K})[56 \mathrm{Bon}], 645(1773 \mathrm{~K})[87 \mathrm{Mil}]$ & $243.2+0.031 \cdot T$ \\
$\mathrm{SiO}_{2}$ & $243.2+0.031 \cdot T[87 \mathrm{NIS}]$ & $T$ \\
\hline
\end{tabular}

Energy parameters used in the cell model [84Gay]

\begin{tabular}{|c|c|c|c|c|c|c|}
\hline system & \multicolumn{2}{|c|}{ cation } & \multicolumn{2}{c|}{$\begin{array}{c}\text { Cells Formation: } \\
W_{i j} / \text { cal }\end{array}$} \\
\hline & $i$ & $j$ & $\left(W_{i j}\right)_{1}$ & $\left(W_{i j}\right)_{2}$ & $\left(E_{i j}\right)_{1}$ & $\left(E_{i j}\right)_{2}$ \\
$\mathrm{SiO}_{2}-\mathrm{CaO}$ & $\mathrm{Si}$ & $\mathrm{Ca}$ & -12500 & 0 & -4500 & 7500 \\
$\mathrm{SiO}_{2}-\mathrm{MnO}$ & $\mathrm{Si}$ & $\mathrm{Mn}$ & -4500 & 0 & -1000 & 5200 \\
\hline
\end{tabular}

$W_{i j}=\left(W_{i j}\right)_{1}+\left(W_{i j}\right)_{2} \cdot N_{i}$

$E_{i j}=\left(E_{i j}\right)_{1}+\left(E_{i j}\right)_{2} \cdot N_{i}$

Table 8. Calculated results for surface tensions of molten oxide mixtures and concentration of $\mathrm{SiO}_{2}$ in surface phase.



The composition with $* *$ is beyond the range where the thermodynamic data and functions are defined in the bulk phase. 
namic data have been taken from several databases containing data that have been assessed according to the CALPHAD approach. The application of the present method to a wider range of systems and fine tuning of the general model parameter $\beta$ as well as the general critical compilation of such properties as $\sigma_{X}$ and $V_{X}$ of the pure substances will enable us to develop a multi-functional thermodynamic databank system. This will be of wide applicability in the evaluation of physico-chemical properties of alloys and other solution-phase-forming systems in conjunction with the simultaneous calculation of the phase equilibria in such systems.

\section{Literature}

32But. Butler, J. A. V: Proc. Roy. Soc. A 135 (1932) 348-375.

48Ska. Skapski, A. S.: J. Chem. Phys. 16 (1948) 389.

500ri. Oriani, R. A.: J. Chem. Phys. 18 (1950) 575-578.

51Kin. King, T. B.: J. Soc. Glass. Technol. 35 (1951) 241-259.

56Bon. Boni, $R$, E.; Derge, G.: J. Metals 8 (1956) 53-59.

57Hoa. Hoar; T. P.; Melford, D. A.: Trans. Faraday Soc. 53 (1957) $315-326$

59Met. Metzger, G.: Z. Phys. Chem. 211 (1959) 1-25.

60Mon. Monma, K.; Sudo, H.: J. Jpn. Inst. Metals 24 (1960) $117-$ 121.

61Mon1. Monma, K.; Sudo, H.: J. Jpn. Inst. Metals 25 (1961) 65-68.

61Mon2. Monma, K.; Sudo, H.: J. Jpn. Inst. Metals 25 (1961) $143-$ 147.

64Dzh. Dzhemilev, N. K.; Popel, S. I.; Tsarevskii, B. V.: Fiz. Metall. i Metalloved. 18 (1964) No. 1, 83

67Muk. Mukai, K.; Sakao, H.; Sano, K.: J. Jpn. Inst. Metals 31 (1967) $928-933$.

69Ono. Ono, K.: Gunji, K.; Araki, T.: J. Jpn. Inst. Metals 33 (1969) 299-304.

71She. Shergin, L. M.; Popel, S. I.; Tsarevskii, B. V.: in: V. N. Eremenko (ed.), Fiz. khim. poverkl. yavlenii rasp., Kiev, Naukova Dumka (1971) 161.

71Sha. Sharma, S. K.; Philbrook, W. O.: Proc. ICSTIS, Suppl. Trans. ISIJ 11 (1971) 569.

73Jou. Joud, J. C.; Eustathopoulos, N.; Bricard, A.; Desre, P.: J. Chim. Phys. 70 (1973) 1290-1294.

74Gun, Gunji, K.; Dan, T.: Trans. ISIJ 14 (1974) 162-169.

74Kaw. Kawai, Y.; Mori, K.; Kishimoto, M.; Ishikura, K.; Shimoda, T.: Tetsu-to-Hagane 60 (1974) 29-37.
77Kau. Kaufman, L. et al.: CALPHAD I (1977) 7; 2 (1978) 55

78Kas. Kasama, A.: Dr. Eng. Thesis, Osaka University (1978) $113-$ 142.

780gi. Ogino, K.; Hara, S.: Tetsu-to-Hagane 64 (1978) 523-532.

79Kub. Kubaschewski, O.; Alcock, C. B.: Metallurgical Thermochemistry, 5th ed., Pergamon Press, Oxford (1979) 326-377.

80Goo. Goodisman, J.: J. Colloid and Interface Sci. 73 (1980) 115123.

81Muk. Mukai, K.; Ishikawa, T.: J. Jpn. Inst. Metals 45 (1981) 147154.

83Pel. Cook, L. P.; McMurdie, H. F. (eds.): Phase Diagrams for Ceramists, Vol. VII, The Amer. Ceram. Soc., Westerville (1983).

84Gay. Gaye, H.; Welfringer, J.: Proc. 2nd Int. Symp. Metall. Slags \& Fluxes (1984) $357-375$

86Gok. Gokcen, N. A.: Statistical Thermodynamics of Alloys, Plenum Press, New York (1986) 288.

86Hay. Hayes, F. H.; Lukas, H. L.; Effenberg, G.; Petzow, G.: Z. Metallkd. 77 (1986) $749-754$.

87Ans. Ansara, I.; Sundman, B.: in: P. S. Glaeser (ed.), Computer Handling and Dissemination of Data, Elsevier Sci. Publ., (1987) $154-158$.

87Mil. Mills, K. C.; Keene, B. J.: Intern. Mater. Rev. 32 (1987) 106 107.

87NIS. NIST Molten Salt Database, National Institute of Standards and Technology (1987).

87Spe. Speiser, R.; Poirier, D. R.; Yeum, K.: Scripta Metall. 21 (1987) 687-692.

88Har. Hara, S.; Ogino, K.: J. Jpn. Inst. Metals 52 (1988) 1098 1102.

88Iid. Iida, T.; Guthrie, R. I. L.: The Physical Properties of Liquid Metals, Clarendon Press, Oxford (1988) 8, 11, 71, 132, 134.

88Pel. Pelton, A. D.: CALPHAD 12 (1988) 127-142.

89 Yeu. Yeum, K. S.; Speiser, R.; Poirier, D. R.: Metall. Trans. B $20 B$ (1989) 693-703.

90Bal. Bale, C. W.; Eriksson, G.: Canad. Metall. Quar. 29 (1990) $105-132$.

91Lac. Lacaze, J.; Sundman, B.: Metall. Trans. A 22A (1991) 2211 2223.

92Nis. Nishizawa, T.: Mat. Trans. JIM. 33 (1992) 713-722.

93Ike. Ikemiya, N.; Umemoto, J.; Hara, S.; Ogino, K.: Iron Steel Inst. Jpn. Intern. 33 (1993) 156-165.

94Tan. Tanaka, T.; Iida, T.: Steel Research 65 (1994) 21-28.

(Received October 23, 1995) 